\title{
Dietary zinc intake and brain cancer in adults: a case-control study
}

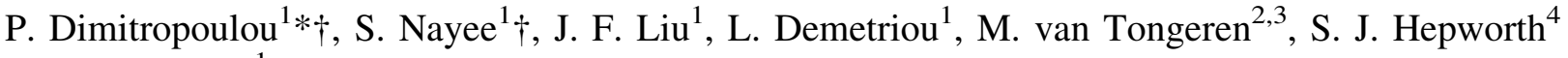 \\ and K. R. Muir ${ }^{1}$ \\ ${ }^{1}$ Division of Epidemiology, University of Nottingham Medical School, E Floor, Queen's Medical Centre, \\ Nottingham NG7 2UH, UK \\ ${ }^{2}$ Centre for Occupational and Environmental Health, Division of Epidemiology and Health Sciences, \\ University of Manchester, Manchester M13 9PL, UK \\ ${ }^{3}$ Institute of Occupational Medicine, Research Avenue North, Riccarton, Edinburgh EH14 4AP, UK \\ ${ }^{4}$ Centre for Epidemiology and Biostatistics, 30 Hyde Terrace, University of Leeds, Leeds LS2 9LN, UK \\ (Received 17 January 2007 - Revised 4 July 2007 - Accepted 31 July 2007)
}

Little is known about the aetiology of brain tumours. One putative factor suggested from animal models is a protective effect of dietary $\mathrm{Zn}$. We tested the hypothesis that increased compared with low dietary $\mathrm{Zn}$ intake is protective against brain tumour development. We conducted a population-based case-control study in the UK, of adults aged 18-69 years, between 2001 and 2004 aiming to identify possible risk factors. Dietary information was collected from 637 cases diagnosed with a glioma or meningioma, and 876 controls. Data were obtained from a self-completed FFQ. Multivariate logistic regression analysis was conducted, adjusting for socio-demographic factors, season of questionnaire return, multivitamin supplementation and energy intake. Although a weak protective effect was observed for the third quartile of intake (normal compared with low intake) in the meningioma group, this was limited to the specific brain tumour subtype and quartile, and was not significant after also adjusting for intake of other elements. Overall there was no significant effect of $\mathrm{Zn}$ intake. No association or dose-response relationship was observed between increased compared with low $\mathrm{Zn}$ intake and risk of glioma or meningioma.

Brain tumours: Zinc: British adults: Gliomas: Meningiomas: Blood-brain barrier

About $50 \%$ of all primary brain tumours are gliomas and $25 \%$ are meningiomas. Gliomas are of three main types (astrocytoma, ependymoma, oligodendroglioma) and are often associated with poor prognosis. Meningiomas are a usually benign type of brain tumour, but some can be 'atypical' and behave more aggressively ${ }^{1}$. A variety of risk factors for brain cancer have been investigated in epidemiological studies, but the evidence for environmental causation is inconsistent. Associations observed include certain medical conditions, exposures to radiation, viruses and chemicals ${ }^{2,3}$. The relationship between dietary trace elements and adult brain tumour aetiology has not yet been fully investigated, as few studies involving trace elements have been conducted ${ }^{2}$.

$\mathrm{Zn}$ is a trace element with antioxidant properties; such elements have been suggested ${ }^{4}$ to be protective against brain tumour development. The main role of $\mathrm{Zn}$ is the maintenance of a healthy central nervous system. $\mathrm{Zn}$ is also important for DNA replication, protein synthesis and metabolism ${ }^{5}$ and oxidative stress protection ${ }^{6}$. The present study was prompted by an a priori hypothesis suggested by animal models. In rat models, $\mathrm{Zn}$ is essential for good neuronal function ${ }^{7-9}$. It has been shown that, in rat glioma cells ${ }^{10}$, increased oxidative stress occurs during Zn deficiency. Ho \& Ames ${ }^{10}$ also reported that, under low intracellular Zn status, proper DNA repair could not be achieved, and after $\mathrm{Zn}$ repletion DNA damage was reversed. Yousef et al. reported a significant increase in the levels of free radicals with $\mathrm{Zn}$ deficiency in the rat brain $^{11}$. In addition, some human case-control studies have yielded inverse associations between $\mathrm{Zn}$ consumption and various cancers, such as oesophageal squamous cell carcinoma ${ }^{12}$ and lung cancer ${ }^{13}$. $\mathrm{Zn}$ adjusted for $\mathrm{Fe}$ intake was inversely associated with upper digestive tract cancer in the follow-up Iowa Women's Health Study ${ }^{14}$. In contrast, a recent casecontrol study found that excessive $\mathrm{Zn}$ intake $(\geq 15.7 \mathrm{mg} / \mathrm{d})$ increases prostate cancer risk in humans ${ }^{15}$.

The concentration of $\mathrm{Zn}$ in the brain is higher than elsewhere in the body (about $150 \mu \mathrm{mol} / \mathrm{l})^{16}$. $\mathrm{Zn}$ is most concentrated in neuron-abundant forebrain regions (for example, hippocampus) serving as an endogenous modulator in neurotransmission ${ }^{17}$. Excess excitation of $\mathrm{Zn}$-containing neurons causes $\mathrm{Zn}$ decrease and neuronal damage. Dietary $\mathrm{Zn}$ deprivation may influence $\mathrm{Zn}$ balance in the brain, resulting in brain dysfunction ${ }^{18}$. Other dietary nutrients affect $\mathrm{Zn}$ concentrations in the brain and blood and, possibly, $\mathrm{Zn}$ availability for transport into the brain through the blood-brain barrier ${ }^{19}$. A number of nutrient elements, such as $\mathrm{Ca}, \mathrm{Fe}, \mathrm{Cu}$ and $\mathrm{P}$, act

Abbreviations: EPIC, European Prospective Investigation into Cancer; UKABTS, United Kingdom Adult Brain Tumour Study.

* Corresponding author: Dr P. Dimitropoulou, fax +44 1223 769007, email pd317@medschl.cam.ac.uk

$\dagger$ P. D. and S. N. have joint first authorship of the present paper. 
as antagonists to $\mathrm{Zn}^{20}$, while other nutrients such as PUFA, fibre and protein facilitate $\mathrm{Zn}$ absorption ${ }^{21,22}$, and some are able to cross the blood-brain barrier via different transport systems.

The present study investigated the a priori hypothesis that higher dietary $\mathrm{Zn}$ levels may be associated with a decreased risk of brain tumour development in a large populationbased case-control study ${ }^{23}$.

\section{Subjects and methods}

The UK Adult Brain Tumour Study (UKABTS) is a population-based case-control study conducted in the Trent, West Midlands, West Yorkshire and central Scotland regions of the UK. A common protocol was followed with identical methods for case ascertainment, control selection and data collection $^{23}$.

Cases were ascertained from hospital departments (for example, neurosurgery, neuro-oncology, neuropathology). Study subjects were aged 18-69 years, resident in the study areas and first diagnosed between 1 December 2000 and 30 June 2003 with a glioma (International Classification of Diseases (ICD)-O-3, topography: C71, morphology: 9380-9411, 9420-9451, 9480, 9505) or meningioma (ICD-O-3, topography: C70, morphology: 9530-9539). Controls were randomly sampled from general practitioner lists and individually matched to cases on age and sex. Non-participating controls were replaced. Eligible subjects were approached by their treating consultant or general practitioner either personally or by letter.

Participants were interviewed using a computer-assisted personal interview system, and then given a FFQ to complete and return by post. Information was collected on dietary intake and use of vitamin, mineral and other dietary supplements. The FFQ includes questions on the average consumption frequency of a medium portion of 132 food items (the most commonly consumed in this population). The subjects were asked about their usual diet during the 2 years preceding diagnosis, to reduce the possibility of reverse causation. Consumption frequency categories varied from 'six or more per day to 'never or less than once per month'.

\section{Data analysis}

Average daily nutrient intake was calculated by multiplying the daily consumption frequency of each food item by the content of the examined nutrient in the respective food item obtained from food composition tables ${ }^{24}$. Data were then processed by the nutritional software based on the program used for the European Prospective Investigation into Cancer (EPIC) study.

Dietary $\mathrm{Zn}$ intake was adjusted for energy intake using the residual method ${ }^{25,26}$ and intake levels were defined by quartiles of the control distribution (lowest category used as the reference group).

Standard unconditional logistic regression was used to estimate OR and $95 \% \mathrm{CI}$ in univariate and multivariate analyses, for gliomas and meningiomas separately. All controls were used in the analyses, as in a previous analysis from the UKABTS on the association between the use of mobile phones and risk of developing brain tumours ${ }^{23}$. In addition to sex, age (in 5-year groups) and region, the multivariate standard logistic regression adjusted simultaneously for the following variables: deprivation category (Townsend score reflecting social class $)^{27}$, season of dietary questionnaire return, multivitamin supplement use and energy intake ${ }^{28}$ (pp. 288-291). Because energy intake may be an important disease predictor, it was included in the regression model together with the nutrient energy-adjusted term $^{28}$ (pp. 288-291).

Subjects' intake of other nutrients besides $\mathrm{Zn}$ was also assessed and included as terms in the regression analysis. The literature suggests that nutrients having a biological relevance to $\mathrm{Zn}$ are the following: $\mathrm{Ca}, \mathrm{Fe}, \mathrm{Cu}, \mathrm{P}$ (the main $\mathrm{Zn}$ antagonists), PUFA, protein and dietary fibre (the last three are thought to affect $\mathrm{Zn}$ absorption and amounts in the body, for example, protein promotes $\mathrm{Zn}$ absorption). These were tested for interaction with $\mathrm{Zn}$, by including interaction terms in the model. Nutrients were also assessed for confounding. In the regression analysis, non-significant nutrient terms were taken out of the model, also provided that excluding them did not largely inflate the standard error while changing very little the corresponding effect size of the examined variable ( $\mathrm{Zn}$ intake). Presented results are those obtained with inclusion of only those nutrients that remained significant.

Data analysis was carried out using the SPSS statistical package (version 11.5; SPSS, Inc., Chicago, IL, USA). All presented $P$ values are two-sided.

\section{Ethical approval}

Approval has been obtained from multi-centre research ethics committees (MREC/99/0/77) and all relevant local research ethics committees.

\section{Results}

Of those who returned an FFQ, 637 cases (436 gliomas, 201 meningiomas) and 876 controls were included in the analyses, after fifteen subjects (eleven cases, four controls) were excluded as their energy intake and BMI were incompatible.

Table 1 gives the response rates - for the dietary FFQ - of cases and controls grouped by tumour type. Table 2 presents the demographic and social characteristics of subjects who returned the dietary FFQ. Table 3 shows the results of analysis by brain tumour subtype. For glioma, no association was seen with $\mathrm{Zn}$ before or after adjustment for confounders. A statistically significant risk reduction for meningioma was observed only in the 3rd quartile of dietary $\mathrm{Zn}$ intake (adjusted OR 0.62 (95\% CI: $0.39,0.99) ; P=0.048)$. The crude results were not significant.

For nutrients biologically relevant to $\mathrm{Zn}$ as suggested from the literature $(\mathrm{Ca}, \mathrm{Fe}, \mathrm{Cu}, \mathrm{P}, \mathrm{PUFA}$, protein and fibre), interaction terms were included in the analysis. However, all interaction terms were found to have non-significant overall $P$ values. The above nutrients were also assessed for confounding, and those significant were entered in the regression analysis.

Confounders remaining significant when examining the $\mathrm{Zn}$-disease association were $\mathrm{Fe}$ for gliomas and $\mathrm{Cu}$ for meningiomas (overall significance $P=0.05$ and $P=0.02$ 
Table 1. Interview and questionnaire response rate in the study

(Frequencies and percentages)

\begin{tabular}{|c|c|c|c|c|c|c|}
\hline & \multicolumn{2}{|c|}{ Glioma } & \multicolumn{2}{|c|}{ Meningioma } & \multicolumn{2}{|c|}{ Control } \\
\hline & $n$ & $\%$ & $n$ & $\%$ & $n$ & $\%$ \\
\hline Registered & 946 & & 310 & & 2472 & \\
\hline Interviewed & 599 & $63 \cdot 3$ & 250 & $80 \cdot 6$ & 1103 & $44 \cdot 6$ \\
\hline FFQ returned & 436 & & 201 & & 876 & \\
\hline Of subjects interviewed & & $72 \cdot 7$ & & $80 \cdot 0$ & & $79 \cdot 4$ \\
\hline Of subjects registered & & $46 \cdot 1$ & & $64 \cdot 8$ & & $35 \cdot 4$ \\
\hline \multicolumn{7}{|l|}{ Reasons for refusal (of subjects registered) } \\
\hline Subject refusal & 103 & $10 \cdot 9$ & 32 & $10 \cdot 3$ & 534 & $21 \cdot 6$ \\
\hline No subject response (non-contactable) & 22 & $2 \cdot 3$ & 8 & $2 \cdot 6$ & 644 & $26 \cdot 1$ \\
\hline Subject too ill or deceased & 183 & $19 \cdot 4$ & 14 & 4.5 & 5 & 0.2 \\
\hline Other* & 39 & $4 \cdot 1$ & 6 & 1.9 & 186 & 7.5 \\
\hline
\end{tabular}

* Includes no permission by consultant or general practitioner, non-English speaking, mental impairment or institutionalised.

respectively). Results appear in Table $4 . \mathrm{Zn}$ intake was significantly correlated with both $\mathrm{Cu}$ intake and $\mathrm{Fe}$ intake at the $P<0.01$ level (the Pearson correlation coefficient between $\mathrm{Zn}$ and $\mathrm{Fe}$ intake for gliomas was $0 \cdot 25$, and between $\mathrm{Zn}$ and $\mathrm{Cu}$ intake for meningiomas was $0 \cdot 27$ ). However, strong collinearity was not observed in the data, as collinearity tests conducted were not significant (gliomas $R^{2} 0.05$; meningiomas $R^{2} 0 \cdot 13$ ). Note that, after taking account of $\mathrm{Cu}$ intake in the analysis for meningiomas, the result for the 3rd quartile was no longer statistically significant (Tables 3 and 4).

We also obtained results for groupings of tertiles according to the RDA recommendations for $\mathrm{Zn}(8-11 \mathrm{mg} / \mathrm{d})$. Results were similar to those already obtained (before adjustment, $P_{\text {gliomas }}=0.561, P_{\text {meningiomas }}=0.125 ;$ after adjustment for Fe, $\mathrm{Cu}$ respectively, $\left.P_{\text {gliomas }}=0 \cdot 577, P_{\text {meningiomas }}=0 \cdot 224\right)$ and no significant associations were observed.

Table 2. Characteristics of cases and controls in the study

(Frequencies and percentages)

\begin{tabular}{|c|c|c|c|c|c|c|}
\hline & \multicolumn{2}{|c|}{ Glioma } & \multicolumn{2}{|c|}{ Meningioma } & \multicolumn{2}{|c|}{ Control } \\
\hline & $n$ & $\%$ & $n$ & $\%$ & $n$ & $\%$ \\
\hline \multicolumn{7}{|l|}{ Region } \\
\hline Central Scotland & 96 & $22 \cdot 0$ & 46 & $22 \cdot 9$ & 207 & $23 \cdot 6$ \\
\hline West Yorkshire & 115 & $26 \cdot 4$ & 59 & $29 \cdot 4$ & 231 & $26 \cdot 4$ \\
\hline West Midlands & 70 & $16 \cdot 1$ & 20 & $10 \cdot 0$ & 141 & $16 \cdot 1$ \\
\hline Trent & 155 & $35 \cdot 6$ & 76 & $37 \cdot 8$ & 297 & 33.9 \\
\hline \multicolumn{7}{|l|}{ Sex } \\
\hline Female & 170 & $39 \cdot 0$ & 150 & $74 \cdot 6$ & 467 & $53 \cdot 3$ \\
\hline Male & 266 & $61 \cdot 0$ & 51 & $25 \cdot 4$ & 409 & $46 \cdot 7$ \\
\hline \multicolumn{7}{|l|}{ Deprivation score } \\
\hline 1 (Least deprived) & 129 & $29 \cdot 6$ & 53 & $26 \cdot 4$ & 267 & $30 \cdot 5$ \\
\hline 2 & 107 & 24.5 & 50 & 24.9 & 202 & $23 \cdot 1$ \\
\hline 3 & 75 & $17 \cdot 2$ & 32 & $15 \cdot 9$ & 156 & $17 \cdot 8$ \\
\hline 4 & 74 & $17 \cdot 0$ & 35 & $17 \cdot 4$ & 145 & $16 \cdot 6$ \\
\hline 5 (Most deprived) & 51 & $11 \cdot 7$ & 31 & $15 \cdot 4$ & 105 & $12 \cdot 0$ \\
\hline Missing & & & & & 1 & $0 \cdot 1$ \\
\hline \multicolumn{7}{|l|}{ Season of FFQ return } \\
\hline Winter (December-February) & 95 & $21 \cdot 8$ & 41 & $20 \cdot 4$ & 197 & $22 \cdot 5$ \\
\hline Spring (March-May) & 80 & $18 \cdot 3$ & 53 & $26 \cdot 4$ & 191 & $21 \cdot 8$ \\
\hline Summer (June-August) & 128 & $29 \cdot 4$ & 68 & $33 \cdot 8$ & 212 & $24 \cdot 2$ \\
\hline Autumn (September-November) & 118 & $27 \cdot 1$ & 32 & $15 \cdot 9$ & 240 & $27 \cdot 4$ \\
\hline Missing & 15 & 3.4 & 7 & 3.5 & 36 & $4 \cdot 1$ \\
\hline \multicolumn{7}{|l|}{ Multivitamin supplementation } \\
\hline Yes & 115 & $26 \cdot 4$ & 54 & $26 \cdot 9$ & 224 & $25 \cdot 6$ \\
\hline No & 314 & $72 \cdot 0$ & 143 & $71 \cdot 1$ & 646 & $73 \cdot 7$ \\
\hline Missing & 7 & 1.6 & 4 & $2 \cdot 0$ & 6 & 0.7 \\
\hline \multicolumn{7}{|l|}{ Age (years) } \\
\hline $18-29$ & 28 & $6 \cdot 4$ & 6 & 3.0 & 43 & 4.9 \\
\hline $30-39$ & 61 & $14 \cdot 0$ & 20 & $10 \cdot 0$ & 129 & $14 \cdot 7$ \\
\hline $40-49$ & 93 & 21.4 & 46 & $22 \cdot 9$ & 190 & $21 \cdot 6$ \\
\hline $50-59$ & 163 & $37 \cdot 4$ & 75 & $37 \cdot 3$ & 307 & $35 \cdot 1$ \\
\hline $60-70$ & 91 & $20 \cdot 8$ & 54 & $26 \cdot 8$ & 207 & $23 \cdot 7$ \\
\hline \multicolumn{7}{|l|}{ Mean energy intake } \\
\hline $\mathrm{kJ}$ & \multicolumn{2}{|c|}{9681.4} & \multicolumn{2}{|c|}{8919.5} & \multicolumn{2}{|c|}{9164.6} \\
\hline kcal & \multicolumn{2}{|c|}{2313.9} & \multicolumn{2}{|c|}{$2131 \cdot 8$} & \multicolumn{2}{|c|}{$2190 \cdot 4$} \\
\hline
\end{tabular}


Table 3. Association between dietary zinc intake and gliomas and meningiomas

(Odds ratios and $95 \%$ confidence intervals)

\begin{tabular}{|c|c|c|c|c|c|c|c|c|}
\hline & Cases $(n)$ & Controls $(n)$ & Crude OR & $95 \% \mathrm{Cl}$ & $P$ & Adjusted OR† & $95 \% \mathrm{Cl}$ & $P$ \\
\hline Glioma & 436 & 876 & & & & & & \\
\hline $\mathrm{Zn}(\mathrm{mg} / \mathrm{d})$ & & & & & 0.265 & & & 0.714 \\
\hline Q1: $2 \cdot 2-9 \cdot 1$ & 129 & 219 & 1.00 & & & 1.00 & & \\
\hline Q2: $9 \cdot 2-10 \cdot 3$ & 101 & 219 & 0.78 & $0.57,1.08$ & 0.135 & 0.87 & $0.62,1.22$ & 0.416 \\
\hline Q3: $10 \cdot 4-12 \cdot 0$ & 96 & 221 & 0.74 & $0.53,1.02$ & 0.065 & 0.82 & $0.58,1.16$ & 0.269 \\
\hline Q4: $12 \cdot 1-21 \cdot 9$ & 110 & 217 & 0.86 & $0.63,1.18$ & 0.352 & 0.92 & $0.66,1.28$ & 0.613 \\
\hline$P$ for trend & & & & & & & & 0.551 \\
\hline Meningioma & 201 & 876 & & & & & & \\
\hline $\mathrm{Zn}(\mathrm{mg} / \mathrm{d})$ & & & & & 0.475 & & & 0.231 \\
\hline Q1: $1 \cdot 1-8 \cdot 8$ & 61 & 219 & 1.00 & & & 1.00 & & \\
\hline Q2: $8.9-10.0$ & 48 & 219 & 0.79 & $0.52,1.20$ & 0.266 & 0.81 & $0.51,1.28$ & 0.365 \\
\hline Q3: $10 \cdot 1-11 \cdot 6$ & 45 & 219 & 0.74 & $0.48,1.13$ & 0.164 & 0.62 & $0.39,0.99$ & $0.048^{\star}$ \\
\hline $\begin{array}{l}\text { Q4: } 11 \cdot 7-21.4 \\
P \text { for trend }\end{array}$ & 47 & 219 & 0.28 & $0.50,1 \cdot 20$ & 0.228 & 0.72 & $0.45,1.13$ & $\begin{array}{l}0.152 \\
0.088\end{array}$ \\
\hline$P$ for trend & & & & & & & & \\
\hline
\end{tabular}

Q, quartile.

* Significant at $P<0.05$ level; two-tailed $P$ value

† Adjusted for age (in 5-year groups), sex, study region, deprivation category (Townsend score), season of FFQ return and multivitamin supplementation.

Additional adjustment of $\mathrm{Zn}$ intake quartiles for dietary intake of vitamins $\mathrm{A}$ (carotene), $\mathrm{B}_{12}, \mathrm{~B}_{6}, \mathrm{C}, \mathrm{D}, \mathrm{E}$, biotin, niacin, retinol, riboflavin and thiamin did not alter any of the results.

\section{Discussion}

$\mathrm{Zn}$ is involved in cell division and differentiation, in tumour cell metabolism ${ }^{5}$, and in the normal development of natural killer cells $^{29}$. Normal Zn levels work against superoxide free radicals $^{29,30}$, and it is often suggested that free radical reduction

Table 4. Association between dietary zinc intake and gliomas and meningiomas adjusted for iron and copper intake respectively

(Odds ratios and $95 \%$ confidence intervals)

\begin{tabular}{|c|c|c|c|c|c|}
\hline & $\begin{array}{c}\text { Cases } \\
(n)\end{array}$ & $\begin{array}{l}\text { Controls } \\
(n) \dagger\end{array}$ & $\begin{array}{c}\text { Adjusted } \\
\text { OR } \neq \S\end{array}$ & $95 \% \mathrm{Cl}$ & $P^{*}$ \\
\hline Glioma & $436 \|$ & 876 & & & \\
\hline Zn (mg/d) & & & & & 0.909 \\
\hline Q1: $2 \cdot 2-9 \cdot 1$ & 129 & 219 & 1.00 & & \\
\hline Q2: $9 \cdot 2-10 \cdot 3$ & 101 & 219 & 0.92 & $0.65,1.31$ & 0.645 \\
\hline Q3: $10 \cdot 4-12 \cdot 0$ & 96 & 221 & 0.88 & $0.62,1.25$ & 0.480 \\
\hline Q4: $12 \cdot 1-21 \cdot 9$ & 110 & 217 & 0.96 & $0.68,1.34$ & 0.797 \\
\hline$P$ for trend & & & & & 0.749 \\
\hline Meningioma & 2019 & 876 & & & \\
\hline $\mathrm{Zn}(\mathrm{mg} / \mathrm{d})$ & & & & & 0.526 \\
\hline Q1: $1 \cdot 1-8 \cdot 8$ & 61 & 219 & 1.00 & & \\
\hline Q2: $8.9-10 \cdot 0$ & 48 & 219 & 0.88 & $0.55,1.40$ & 0.593 \\
\hline Q3: $10 \cdot 1-11 \cdot 6$ & 45 & 219 & 0.70 & $0.43,1.14$ & 0.147 \\
\hline Q4: $11 \cdot 7-21 \cdot 4$ & 47 & 219 & 0.79 & $0.48,1.29$ & 0.345 \\
\hline$P$ for trend & & & & & 0.242 \\
\hline
\end{tabular}

Q, quartile.

*Two-tailed $P$ values; $P<0.05$ significance level.

†Energy-adjusted mean intake of $\mathrm{Fe}$ and $\mathrm{Cu}$ was 28.82 and $2.42 \mathrm{mg}$ respectively for controls.

‡For glioma, adjusted for age (in 5-year groups), sex, study region, deprivation category (Townsend score), season of FFQ return, multivitamin supplementation and Fe intake.

$\S$ For meningioma, adjusted for age (in 5-year groups), sex, study region, deprivation category (Townsend score), season of FFQ return, multivitamin supplementation and $\mathrm{Cu}$ intake.

|| Energy-adjusted mean Fe intake for glioma cases was $27.19 \mathrm{mg}$

9 Energy-adjusted mean $\mathrm{Cu}$ intake for meningioma cases was $2.46 \mathrm{mg}$. may help to lower cancer risk ${ }^{31,32}$. Zn deficiency is prevalent in some cancers, and low $\mathrm{Zn}$ levels may reduce the number of helper T-cells and thymic hormone levels ${ }^{33}$, thereby weakening immune function ${ }^{29}$. Cancer, in general, arises more frequently against a background of immunodeficiency ${ }^{33}$.

On the other hand, in animal models with existing tumours, depletion of dietary $\mathrm{Zn}$ has been proven to suppress tumour growth $^{34,35}$. Excess $\mathrm{Zn}$ intake has been linked to disease and toxicity $^{31}$. Reduced immune function can result from both excessive $\mathrm{Zn}$ intake $^{36}$ and low $\mathrm{Zn}$ intake, as mentioned earlier. The above contradicting evidence shows that the mechanisms behind the $\mathrm{Zn}$ intake-brain tumour relationship are not yet fully comprehended; thus, a balanced intake is recommended $^{37}$.

Blood-brain barrier dysfunction has been linked to neurological conditions and brain tumour development, i.e. the barrier is usually non-existent in brain tumours ${ }^{38}$. Intake of normal $\mathrm{Zn}$ levels is required for a healthy blood-brain barrier $^{19}$, as enhanced dietary $\mathrm{Zn}$ consumption does not affect $\mathrm{Zn}$ concentration in the brain except for the case where $\mathrm{Zn}$ deprivation already exists ${ }^{18}$.

Results of a recent study show that $\mathrm{Zn}$ depletion damages non-brain endothelial cells; however, the brain endothelial cells respond by enhancing barrier property ${ }^{39}$. Levels of other elements in the brain play an important role, as interaction with elements transported across the blood-brain barrier affects $\mathrm{Zn}$ absorption and its concentrations in the brain and, subsequently, its contribution to normal brain function. $\mathrm{Fe}$ and $\mathrm{Cu}$ are both elements that can pass through the blood-brain barrier and affect $\mathrm{Zn}$ levels ${ }^{20}$. Fe is transported through the barrier by $\mathrm{p} 97^{40}$ and $\mathrm{Cu}$ via a $\mathrm{Cu}$-transporting ATPase mechanism ${ }^{41}$.

\section{Potential areas of bias}

Participation levels were relatively low amongst cases. This was due mainly to disease severity; patients were very ill or died before being recruited. As reported previously ${ }^{23}$, highgrade glioma cases were less likely to be interviewed than those diagnosed with a low-grade tumour. Control 
participation was also low, a problem for many populationbased studies ${ }^{28}$ (pp. 9-11, 90-91). This may have introduced selection bias amongst controls, as previously reported controls taking part in the study tended to be more affluent than non-interviewed controls ${ }^{23}$. Controls used may have better nutritional regimens than the general population. Deprivation category was adjusted for in the analysis, although the bias cannot be fully removed.

The FFQ method is cheap, easy to administer, and provides quick intake estimates ${ }^{28}$ (pp. 74-91). Although extreme misclassification has been shown to be minimal ${ }^{42}$, another problem associated with use of FFQ in case-control studies is that questions may have been misinterpreted by some subjects $^{28}$ (pp. 101-124, 302-304).

Energy adjustment, as carried out in the present study, minimises errors resulting from general food consumption over- or under-reporting ${ }^{25}$. The dietary FFQ used (based on the EPIC FFQ) containing questions on as many as 132 food items commonly consumed in the UK might also have reduced underreporting of food consumption ${ }^{42}$.

In the study, the frequency question was combined with a specific 'medium portion' size and this can present cognitive challenges for subjects ${ }^{43}$. However, several studies have found that consumption frequency is the main determinant of between-person variation in measured dietary intake levels and that it is positively correlated with portion size ${ }^{43}$.

There is concern that cases will report on their diets differently to controls ${ }^{44}$. Brain tumours are associated with impaired memory and concentration ${ }^{45}$ and current dietary habits also considerably affect responses regarding previous $\operatorname{diet}^{42}$. However, recall bias is reduced by recruiting incident cases ${ }^{28}$ (pp. 153-155), as has been done in the present study.

\section{Missing values}

The suggestive result before $\mathrm{Cu}$ inclusion could potentially be stronger, as dietary assessment through FFQ inherently produces measurement error and generally modest relative risks $^{28}$. In that respect, missing values are potentially a source of bias in the present study. Some foods (for example, cooked vegetables), tend to be more frequently omitted than others ${ }^{28}$ (pp. 61-67) and respondents tend to selectively omit foods they never or seldom eat ${ }^{46}$. After conducting a missing values analysis, we found that there were significantly more missing values for cases than controls. Also, responses on $\mathrm{Zn}$-containing foods are different from those on food items containing $\mathrm{Cu}$. Of missing values for $\mathrm{Zn}, 64 \%$ are for foods with zero $\mathrm{Zn}$ content; the respective percentage for $\mathrm{Cu}$ is $56 \%$. Although $\mathrm{Cu}$ has $4 \%$ of its missing values for foods containing $5.8-9.9 \mathrm{mg}$ $\mathrm{Cu}$ (the highest composition range), the highest percentage $(22 \%)$ of missing values is accumulated in the $0.01-$ $0.09 \mathrm{mg}$ range (lowest). However, the highest percentage $(31 \%)$ of missing values for $\mathrm{Zn}$ is found in the $0.1-$ $1.0 \mathrm{mg}$ range. Therefore, more of the missing values for $\mathrm{Zn}$ are for foods with a moderate composition of $\mathrm{Zn}$, while more of the missing values for $\mathrm{Cu}$ are for foods low in $\mathrm{Cu}$, indicating that $\mathrm{Zn}$ intake may have been underestimated. It would be interesting to see if $\mathrm{Zn}$ amounts greater than used here would yield an effect.

\section{Conclusions}

In this dietary investigation of the UKABTS, no associations were found between dietary $\mathrm{Zn}$ intake and risk of glioma or meningioma. Overall, our findings are non-significant. The specific hypothesis on a protective effect of increased compared with low levels of dietary $\mathrm{Zn}$ against glioma or meningioma formation is not supported.

There is no strong multi-collinearity in the data. Therefore, controlling for a confounding effect of $\mathrm{Fe}$ and $\mathrm{Cu}$ intake is helpful, as relationships of dietary elements are complex and it is difficult to separate the effects of one element alone from the effects of others.

\section{Acknowledgements}

The dietary analysis of the study was funded by Cancer Research UK grant number C18182/A5769. The authors wish to thank P. A. McKinney and M. Grainge for their expert advice and comments. We acknowledge the support of the study steering group chaired by David Coggon. The nutritional database version based on EPIC was designed by $\mathrm{Dr}$ A. Lophatananon. The UKABTS received funding from the Mobile Telecommunications, Health and Research programme and as part of the Interphone study from the European Union, the Mobile Manufacturers Forum, and the Global System for Mobile Communications (GSM) Association through the scientifically independent Union Internationale Contre le Cancer, the Health and Safety Executive, the Department of Health, the UK network operators $(\mathrm{O} 2$, Orange, T-Mobile, Vodafone, 3) and the Scottish Executive.

We wish to thank the following neuropathologists, neuroradiologists, neurosurgeons, neuro-oncologists, clinical oncologists, neurologists, specialist nurses, administrators and secretaries: P. Barlow, I. Bone, J. Brown, J. Crowther, R. Dolan, L. Dunn, M. O. Fitzpatrick, M. Fraser, R. Grant, A. Gregor, J. Ironside, R. Johnstone, K. W. Lyndsay, S. Macnamara, J. Mair, R. Mills, L. Myles, B. O'Reilly, V. Papanastassiou, R. Rampling, M. Russell, D. Sim, P. Statham, J. Steers, W. A. Taylor, G. Teasdale and I. Whittle (Scotland); J. M. Anderson, P. Barber, C. R. Barraclough, P. Bennett, H. G. Boddie, A. Brind, P. Carey, M. Choksey, M. Christie, R. N. Corston, G. S. Cruickshank, A. Detta, P. Dias, S. J. Ellis, G. Flint, D. A. Francis, A. H. Grubneac, S. P. Harland, C. Hawkins, T. Heafield, R. C. Hughes, D. G. Jamieson, A. Logan, C. H. A. Meyer, R. Mitchell, K. Morrison, P. Newman, D. Nicholl, S. Nightingale, H. S. Pall, J. R. Ponsford, A. Shehu, J. Singh, J. A. Spillane, P. Stanworth, B. Summers, A. R. Walsh, J. Wasserberg, A. C. Williams, J. Winer and S. Zygmunt (West Midlands); R. J. Abbott, S. Adams, R. D. Ashpole, R. D. E. Battersby, L. Blumhardt, P. Byrne, M. Cartmill, S. C. Coley, P. Critchley, B. B. Faraj, A. Gibson, P. Griffiths, R. Grunwald, T. J. Hodgson, D. T. Hope, S. Howell, D. Jefferson, D. Jelinek, N. Jordan, A. Kemeny, M. C. Lawden, J. Lowe, N. Messios, K. Pardoe, S. Price, I. F. Pye, M. Radatz, I. Robertson, K. Robson, C. Romanowski, G. Sawle, B. Sharrock, P. Shaw, C. Smith, W. Temperley, G. Venables, B. White, A. M. Whiteley and A. J. Wills (Trent); A. S. N. Al-Din, D. Ash, J. Bamford, M. Bond, G. Bonsor, L. Bridges, B. Carey, A. Chakrabarty, 
P. Chumas, D. Dafalla, H. Ford, G. E. Gerrard, P. J. Goulding, J. Howe, S. Jamieson, M. H. Johnson, L. A. Louizou, P. Marks, M. Nelson, S. Omer, N. Phillips, S. Ross, I. Rothwell, H. Spokes, J. Straiton, G. Towns, A. Tyagi, P. Vanhille and M. Busby (West Yorkshire).

K. R. M. and M. vT. were responsible for the design and implementation of the study. P. D. and J. F. L. conducted the dietary and statistical analyses. P. D. and S. N. wrote the first draft of the paper, PD wrote all subsequent drafts. L. D. conducted data entry and checking. K. R. M., J. F. L., S. J. H. and M. vT. provided comments on the draft. The authors declare that there are no conflicts of interest.

\section{Electronic Publications Rights}

As the author(s) and beneficial owner(s) of the entire copyright and all other rights in the research paper entitled DIETARY ZINC INTAKE AND BRAIN CANCER IN ADULTS: A CASE-CONTROL STUDY

we hereby, reserve, with the consent of our employers, for the benefit of Cancer Research UK, in recognition of the funding for the work described, the non-exclusive right to access and to distribute this paper, a summary of this paper and any extracts from this paper electronically and in paper form, unencumbered and free of any charges provided that this use is solely for the purposes of promotion and fundraising and in pursuit of the charitable aims of Cancer Research UK. These rights are reserved in accordance with the duty that Cancer Research UK has as a UK Registered Charity to make available information about the work that it has funded.

Dimitropoulou Polyxeni

Nayee Suneet

Liu Jo-Fen

Demetriou Lia

van Tongeren Martie

Hepworth Sarah

Muir Kenneth

$17 / 01 / 07$

\section{References}

1. Cancer Research UK (2007)About brain tumours - types of primary brain tumours. http://www.cancerhelp.org.uk/help/default.asp?page $=5014$ (accessed June 2007).

2. Wrensch M, Minn Y, Chew T, Bondy M \& Berger MS (2002) Epidemiology of primary brain tumors: current concepts and review of the literature. Neuro Oncol 4, 278-299.

3. Schwartzbaum JA, Fisher JL, Aldape KD \& Wrensch M (2006) Epidemiology and molecular pathology of glioma. Nat Clin Pract Neurol 2, 494-503.

4. Chen H, Ward MH, Tucker KL, Graubard BI, McComb RD, Potischman NA, Weisenburger DD \& Heineman EF (2002) Diet and risk of adult glioma in eastern Nebraska, United States. Cancer Causes Control 13, 647-655.

5. Vallee BL \& Falchuk KH (1993) The biochemical basis of zinc physiology. Physiol Rev 73, 79-118.

6. Stehbens WE (2003) Oxidative stress, toxic hepatitis, and antioxidants with particular emphasis on zinc. Exp Mol Pathol 75, 265-276.

7. Colvin RA, Davis N, Nipper RW \& Carter PA (2000) Zinc transport in the brain: routes of zinc influx and efflux in neurons. J Nutr 130, Suppl. 5S, 1484S-1487S.
8. Bediz CS, Baltaci AK, Mogulkoc R \& Oztekin E (2006) Zinc supplementation ameliorates electromagnetic field-induced lipid peroxidation in the rat brain. Tohoku J Exp Med 208, 133-140.

9. Warming S, Rachel RA, Jenkins NA \& Copeland NG (2006) Zfp423 is required for normal cerebellar development. Mol Cell Biol 26, 6913-6922.

10. Ho E \& Ames BN (2002) Low intracellular zinc induces oxidative DNA damage, disrupts p53, NFkB, and AP1 DNA binding, and affects DNA repair in a rat glioma cell line. Proc Natl Acad Sci U S A 99, 16770-16775.

11. Yousef MI, El-Hendy HA, El-Demerdash FM \& Elagamy EI (2002) Dietary zinc deficiency induced changes in the activity of enzymes and the levels of free radicals, lipids and protein electrophoretic behavior in growing rats. Toxicology 175, 223-234.

12. Lu H, Cai L, Mu LN, et al. (2006) Dietary mineral and trace element intake and squamous cell carcinoma of the esophagus in a Chinese population. Nutr Cancer 55, 63-70.

13. Zhou W, Park S, Liu G, Miller DP, Wang LI, Pothier L, Wain JC, Lynch TJ, Giovannucci E \& Christiani DC (2005) Dietary iron, zinc, and calcium and the risk of lung cancer. Epidemiology 16, 772-779.

14. Lee DH, Anderson KE, Folsom AR \& Jacobs DR Jr (2005) Heme iron, zinc and upper digestive tract cancer: the Iowa Women's Health Study. Int J Cancer 117, 643-647.

15. Gallus S, Foschi R, Negri E, Talamini R, Franceschi S, Montella M, Ramazzotti V, Tavani A, Dal Maso L \& La Vecchia C (2007) Dietary zinc and prostate cancer risk: a case-control study from Italy. Eur Urol (Epublication ahead of print version).

16. Mocchegiani E, Bertoni-Freddari C, Marcellini F \& Malavolta M (2005) Brain, aging and neurodegeneration: role of zinc ion availability. Prog Neurobiol 75, 367-390.

17. Frederickson CJ, Suh SW, Silva D, Frederickson CJ \& Thompson RB (2000) Importance of zinc in the central nervous system: the zinc-containing neuron. $J$ Nutr 130, Suppl. 5S, 1471S-1483S.

18. Takeda A (2000) Movement of zinc and its functional significance in the brain. Brain Res Brain Res Rev 34, 137-148.

19. Takeda A (2004) Essential trace metals and brain function. Yakugaku Zasshi 124, 577-585.

20. Sandstrom B (2001) Micronutrient interactions: effects on absorption and bioavailability. $B r \quad J$ Nutr 85, Suppl. 2, S181-S185.

21. Greger JL \& Snedeker SM (1980) Effect of dietary protein and phosphorus levels on the utilization of zinc, copper and manganese by adult males. J Nutr 110, 2243-2253.

22. Solomons NW \& Cousins RJ (1984) Zinc. In Absorption and Malabsorption of Mineral Nutrients, pp. 125-197 [NW Solomons and IH Rosenberg, editors]. New York: Liss.

23. Hepworth SJ, Schoemaker MJ, Muir KR, Swerdlow AJ, van Tongeren MJ \& McKinney PA (2006) Mobile phone use and risk of glioma in adults: case-control study. BMJ 332, 883-887.

24. Holland B, Welch AA, Unwin ID, Buss DH, Paul AA \& Southgate DAT (1991) McCance and Widdowson's The Composition of Foods, 5th ed. Cambridge: The Royal Society of Chemistry; London: Ministry of Agriculture, Fisheries and Food.

25. Willett WC, Howe GR \& Kushi LH (1997) Adjustment for total energy intake in epidemiologic studies. Am J Clin Nutr 65, Suppl. 4, 1220S-1231S.

26. Willett WC (2000) Diet and cancer. Oncologist 5, 393-404.

27. Townsend P, Phillimore P \& Beattie A (1988) Health and Deprivation: Inequality and the North. New York: Croom Helm.

28. Willett WC (editor) (1998) Nutritional Epidemiology, 2nd ed. New York: Oxford University Press. 
29. Shankar AH \& Prasad AS (1998) Zinc and immune function: the biological basis of altered resistance to infection. Am J Clin Nutr 68, Suppl. 2, 447S-463S.

30. Williams RJ, Spencer JP, Goni FM \& Rice-Evans CA (2004) Zinc-histidine complex protects cultured cortical neurons against oxidative stress-induced damage. Neurosci Lett 371, 106-110.

31. Chan S, Gerson B \& Subramaniam S (1998) The role of copper, molybdenum, selenium, and zinc in nutrition and health. Clin Lab Med 18, 673-685.

32. Prasad AS, Bao B, Beck FW, Kucuk O \& Sarkar FH (2004) Antioxidant effect of zinc in humans. Free Radic Biol Med 37, 1182-1190.

33. Hadden JW (2003) Immunodeficiency and cancer: prospects for correction. Int Immunopharmacol 3, 1061-1071.

34. Takeda A, Tamano H \& Oku N (2003) Alteration of zinc concentrations in the brain implanted with C6 glioma. Brain Res 965, 170-173.

35. Takeda A, Goto K \& Okada S (1997) Zinc depletion suppresses tumor growth in mice. Biol Trace Elem Res 59, 23-29.

36. Santillo VM \& Lowe FC (2006) Role of vitamins, minerals and supplements in the prevention and management of prostate cancer. Int Braz J Urol 32, 3-14.

37. Naganska E \& Matyja E (2006) Apoptotic neuronal changes enhanced by zinc chelator-TPEN in organotypic rat hippocampal cultures exposed to anoxia. Folia Neuropathol 44, 125-132.

38. Rapoport SI (1990) Blood-brain barrier disruption in braintumor therapy. J Neurosurg 73, 475-477.
39. Di Cello F, Siddharthan V, Paul-Satyaseela M \& Kim KS (2005) Divergent effects of zinc depletion in brain vs non-brain endothelial cells. Biochem Biophys Res Commun 335, 373-376.

40. Moroo I, Ujiie M, Walker BL, Tiong JW, Vitalis TZ, Karkan D, Gabathuler R, Moise AR \& Jefferies WA (2003) Identification of a novel route of iron transcytosis across the mammalian blood-brain barrier. Microcirculation 10, 457-462.

41. Qian Y, Tiffany-Castiglioni E, Welsh J \& Harris ED (1998) Copper efflux from murine microvascular cells requires expression of the Menkes disease Cu-ATPase. J Nutr 128, 1276-1282.

42. Thompson FE \& Byers T (1994) Dietary assessment resource manual. J Nutr 124, Suppl. 11, 2245S-2317S.

43. Hunter DJ, Sampson L, Stampfer MJ, Colditz GA, Rosner B \& Willett WC (1988) Variability in portion sizes of commonly consumed foods among a population of women in the United States. Am J Epidemiol 127, 1240-1249.

44. Friedenreich CM, Howe GR \& Miller AB (1993) Recall bias in the association of micronutrient intake and breast cancer. $J$ Clin Epidemiol 46, 1009-1017.

45. Nelson M \& Bingham SA (1997) Assessment of food consumption and nutrient intake. In Design Concepts in Nutritional Epidemiology, 2nd ed. [BM Margetts and $\mathrm{M}$ Nelson, editors]. Oxford and New York: Oxford University Press.

46. Caan BJ, Lanza E, Schatzkin A, Coates AO, Brewer BK, Slattery ML, Marshall JR \& Bloch A (1999) Does nutritionist review of a self-administered food frequency questionnaire improve data quality? Public Health Nutr 2, 565-569. 